\title{
2'-Hydroxyflavanone effectively targets RLIP76-mediated drug transport and regulates critical signaling networks in breast
} cancer This article has been corrected. Correction in Oncotarget. 2022; 13:331-331.

Lokesh Dalasanur Nagaprashantha ${ }^{1}$, Jyotsana Singhal ${ }^{1,2}$, Hongzhi Li $^{3}$, Charles Warden ${ }^{4}$, Xueli Liu ${ }^{5}$, David Horne ${ }^{2}$, Sanjay Awasthi ${ }^{6}$, Ravi Salgia ${ }^{1}$ and Sharad S. Singhal ${ }^{1}$

\footnotetext{
${ }^{1}$ Department of Medical Oncology, Beckman Research Institute of City of Hope, Comprehensive Cancer Center and National Medical Center, Duarte, CA 91010, USA

${ }^{2}$ Department of Molecular Medicine, Beckman Research Institute of City of Hope, Comprehensive Cancer Center and National Medical Center, Duarte, CA 91010, USA

${ }^{3}$ Department of Computational Therapeutics, Beckman Research Institute of City of Hope, Comprehensive Cancer Center and National Medical Center, Duarte, CA 91010, USA

${ }^{4}$ Department of Genomic Core, Beckman Research Institute of City of Hope, Comprehensive Cancer Center and National Medical Center, Duarte, CA 91010, USA

${ }^{5}$ Department of Information Sciences \& Biostatistics, Beckman Research Institute of City of Hope, Comprehensive Cancer Center and National Medical Center, Duarte, CA 91010, USA

${ }^{6}$ Department of Internal Medicine, Texas Tech University Health Sciences Center, Lubbock, TX 79430, USA

Correspondence to: Sharad S. Singhal, email: ssinghal@coh.org

Keywords: breast cancer; 2'-hydroxyflavanone; ER

Received: January 30, $2018 \quad$ Accepted: March 06, $2018 \quad$ Published: April 06, 2018

Copyright: Nagaprashantha et al. This is an open-access article distributed under the terms of the Creative Commons Attribution License 3.0 (CC BY 3.0), which permits unrestricted use, distribution, and reproduction in any medium, provided the original author and source are credited.
}

\section{ABSTRACT}

Breast cancer (BC) is the most common cancer in women. Estrogen, epidermal growth factor receptor 2 (ERBB2, HER2), and oxidative stress represent critical mechanistic nodes associated with BC. RLIP76 is a major mercapturic acid pathway transporter whose expression is increased in BC. In the quest of a novel molecule with chemopreventive and chemotherapeutic potential, we evaluated the effects of 2'-Hydroxyflavanone (2HF) in BC. $2 \mathrm{HF}$ enhanced the inhibitory effects of RLIP76 depletion and also inhibited RLIP76-mediated doxorubicin transport in BC cells. RNA-sequencing revealed that $2 \mathrm{HF}$ induces strong reversal of the gene expression pattern in ER+MCF7, HER2 ${ }^{+}$SKBR3 and triple-negative MDA-MB-231 BC cells with minimal effects on MCF10A normal breast epithelial cells. 2HF down regulated ERa and enhanced inhibitory effects of imatinib mesylate/Gleevec in MCF7 cells. 2HF also down regulated ERa and HER2 gene networks in MCF7 and SKBR3 cells, respectively. $2 \mathrm{HF}$ activated TP53 and inhibited TGF $\beta 1$ canonical pathway in MCF7 and MDA-MB-231 BC cells. $2 \mathrm{HF}$ also regulated the expression of a number of critical prognostic genes of MammaPrint panel and their upstream targets including TP53, CDKN2A and MYC. The collective findings from this study provide a comprehensive, direct and integrated evidence for the benefits of $\mathbf{2 H F}$ in targeting major and clinically relevant mechanistic regulators of $\mathrm{BC}$. 


\section{INTRODUCTION}

Breast cancer $(\mathrm{BC})$ remains the most common malignancy in women in spite of rapid advances in the methods for early detection and multi-modality interventions [1]. The interplay between the estrogen receptor (ER), epidermal growth factor receptor 2 (ERBB2 or HER2/neu), cellular proliferative and apoptotic networks collectively influence $\mathrm{BC}$ incidence and response to therapy [2]. The action of estrogen represents an endogenous chronic carcinogenic stimulus that determines both disease aggressiveness and prognosis in $\mathrm{BC}$ [3]. Amplification of HER2 is another major factor associated with both breast tumor response to clinical interventions and recurrence risk [4]. Mercapturic acid pathway (MAP) determines the intracellular levels of toxic lipid peroxidation products, tumor survival, chemo- and radio-sensitivity [5]. In MAP, RLIP76 (a ral-interacting protein; RalBP1) functions as a stress-responsive and ATP-dependent glutathione-electrophile conjugate (GSE) transporter of toxic lipid peroxidation products and chemotherapy drugs [6]. Along with being a critical factor regulating clathrin-dependent endocytosis (CDE), RLIP76 is strongly linked to resistance to chemical as well as radiant stresses [7]. RLIP76 depletion does not affect the survival of normal cells while causing effective regression of multiple organ tumors including lung, colon, kidneys, skin, and pancreas [8-10]. RLIP76 is overexpressed in human $\mathrm{BC}$ making it a novel candidate for $\mathrm{BC}$ interventions [11].

Treatment of localized BC with surgery, radiation, chemotherapy and hormonal therapy is insufficient to control and eradicate $\mathrm{BC}$ as evident from the development of metastatic $\mathrm{BC}$ in up to $40 \%$ of women initially presenting with localized disease [12]. Natural phytochemicals have been a major source of both preventive and therapeutic lead compounds. More than $>60 \%$ of the FDA approved drugs have been characterized and further developed from natural sources [13]. Citrus phytochemicals have sustained a strong focus of developmental research in the area of cancer prevention and/or therapy [14]. The citrus phytochemical 2'-Hydroxyflavanone (2HF) has shown promising efficacy against breast cancer [15]. According to Lipinski Rule of 5 , for a drug/test compound to be orally active in humans, the total polar surface area should not be greater than $140 \AA^{2}$, molar refractivity should be between 40 and 130 , molecular weight should be less than 500 , hydrogen bond donors should not be more than 5, hydrogen bond acceptors should not be more than 10 and partition coefficient $(\log \mathrm{P})$ should not be greater than 5 [16]. 2HF [Canonical SMILES: $\mathrm{C} 1 \mathrm{C} \quad(\mathrm{OC} 2=\mathrm{CC}=\mathrm{CC}=\mathrm{C} 2 \mathrm{C} 1=\mathrm{O})$ $\mathrm{C} 3=\mathrm{CC}=\mathrm{CC}=\mathrm{C} 3 \mathrm{O}$ ] satisfies all the criteria of Lipinski Rule of 5 which makes it an ideal compound for regular use. Low total polar surface area of 2HF (TPSA, TPSA of 2HF-46.53) is a significant factor that could potentially facilitate better membrane penetration and permeability (Table 1) [17]. Hence, we investigated the efficacy of 2HF in regulating RLIP76 transport, docking of 2HF with RLIP76, ER $\alpha$ and HER2 along with elucidating the 2HF induced regulation of gene expression in BC.

\section{RESULTS}

\section{Analyses of the effect of $2 \mathrm{HF}$, alone and in combination with RLIP76 inhibition, on BC survival and ${ }^{14} \mathrm{C}$-Doxorubicin $\left({ }^{14} \mathrm{C}\right.$-DOX) transport}

RLIP76 is a multi-functional regulator of the cellular levels of oxidative stress and lipid peroxidation products and intracellular concentration of chemotherapy drugs like DOX, which is widely used in BC therapy [6-10]. $2 \mathrm{HF}$ at 5 and $10 \mu \mathrm{M}$ concentrations led to inhibition of the survival of BC cells (MCF7: $16 \pm 4 \%$ and $23 \pm 4$ $\%$ at 5 and $10 \mu \mathrm{M} 2 \mathrm{HF}$, respectively; MDA-MB-231: 19 $\pm 4 \%$ and $31 \pm 6 \%$ at 5 and $10 \mu \mathrm{M} 2 \mathrm{HF}$, respectively) and the addition of anti-RLIP76 IgG $(10 \mu \mathrm{g} / \mathrm{ml}$ conc.) led to a stronger inhibition of BC cell survival $(45 \pm 6$ $\%$ and $64 \pm 6 \%$ in MCF7 cells, and $52 \pm 5 \%$ and 72 $\pm 7 \%$ in MDA-MB-231 cells, at 5 and $10 \mu \mathrm{M} 2 \mathrm{HF}$ concentrations, respectively) (Figure 1A and 1B). DOX is a common drug transported by RLIP76 [6, 18, 19]. Hence, we performed drug-transport studies to see the effect of $2 \mathrm{HF}$ on ${ }^{14} \mathrm{C}$-DOX transport. The ATP-dependent ${ }^{14} \mathrm{C}$-DOX transport was conducted in purified reconstituted proteoliposomes prepared from MCF7 and MDA-MB-231 cells. The ${ }^{14} \mathrm{C}$-DOX transport was significantly inhibited by $2 \mathrm{HF}(10$ and $20 \mu \mathrm{M})$ and anti-RLIP76 $\operatorname{IgG}(10 \mu \mathrm{g} / \mathrm{ml})$. The combination of both anti-RLIP76 IgG $(10 \mu \mathrm{g} / \mathrm{ml})$ and $2 \mathrm{HF}(20 \mu \mathrm{M})$ resulted in stronger inhibition of ATPdependent ${ }^{14} \mathrm{C}$-DOX transport activity (Figure $1 \mathrm{C}$ and $1 \mathrm{D}$ ).

\section{Molecular docking studies on 2HF interaction with RLIP76, ER $\alpha$ and epidermal growth factor receptor 2 (HER2)}

We conducted docking studies to study the interaction between 2HF and RLIP76, ER $\alpha$ and HER2 by employing Schordinger Glide docking software [20, 21]. $2 \mathrm{HF}$ formed hydrogen bonds with tyrosine $\left(\mathrm{Y}^{231}\right)$, lysine $\left(\mathrm{K}^{268}\right)$ and alanine $\left(\mathrm{A}^{264}\right)$ residues of RLIP76 with a docking score of $-10.5 \mathrm{kcal} / \mathrm{mol}$ at its previously known ligand (DNP-SG)-binding site [7, 10] (Figure 2A). 2HF also showed preferred binding at the ATP-binding pocket of HER2 by forming hydrogen bond to methionine $\left(\mathrm{M}^{793}\right)$ with a docking score of $-10.2 \mathrm{kcal} / \mathrm{mol}$ (Figure 2B). $2 \mathrm{HF}$ interacted with the ligand-binding site of ER $\alpha$ through hydrophobic interactions at a docking score of $-9.7 \mathrm{kcal} /$ $\mathrm{mol}$ (Figure 2C). These studies were informative on the potential of $2 \mathrm{HF}$ to act upon critical nodes of $\mathrm{BC}$ signaling by direct binding to RLIP76, ER $\alpha$ and HER2. 
Table 1: 2HF characteristics as a small molecule drug candidate according to Lipinski Rule of 5

\begin{tabular}{lccccccc}
\hline Canonical Smiles & TPSA & MR & $\begin{array}{c}\text { Molecular } \\
\text { Weight }\end{array}$ & HBD & HBA & Log P & $\begin{array}{c}\text { Lipinski } \\
\text { Rule of 5 }\end{array}$ \\
\hline $\mathrm{C} 1 \mathrm{C}(\mathrm{OC} 2=\mathrm{CC}=\mathrm{CC}=\mathrm{C} 2 \mathrm{C} 1=\mathrm{O}) \mathrm{C} 3=\mathrm{CC}=\mathrm{CC}=\mathrm{C} 3 \mathrm{O}$ & 46.53 & 67.5245 & 240.25398 & 1 & 3 & 3.0987 & $100 \%$ \\
\hline
\end{tabular}

HBA-Hydrogen Bond Acceptors; HBD-Hydrogen Bond Donors; logP- Partition Coefficient; MR- Molar Refractivity; TPSA-Total Polar Surface Area.

Source: TargetNet- http://targetnet.scbdd.com/calcnet/index_rule/

The docking ability of 2HF to RLIP76, ER $\alpha$ and HER2 along with its ability to enhance inhibitory effect of RLIP76 depletion on BC survival, and decrease RLIP76mediated DOX transport together provided a strong rationale for the mechanistic regulatory role of $2 \mathrm{HF}$ in $\mathrm{BC}$. In this regard, we further conducted gene expression studies following $2 \mathrm{HF}$ treatment in $\mathrm{BC}$ cells.

\section{Analyses of global gene expression changes following $2 \mathrm{HF}$ treatment}

The MCF10A normal breast epithelial cells and $\mathrm{ER}^{+} \mathrm{MCF} 7, \mathrm{HER} 2^{+}$SKBR3 and triple-negative MDAMB-231 BC cells were treated with $50 \mu \mathrm{M} 2 \mathrm{HF}$, RNA was isolated at $24 \mathrm{~h}$ and RNA-Seq analyses was done at City of Hope Genomics Core as described in the Methods Section. Three biological replicates were used for each cell line and for each of the treatment groups. Reads were aligned using TopHat (2.0.8b) to human genome hg19 (Supplementary Tables 1 and 2). The gene expression profiles and curves $(\log 2 \mathrm{FPKM}+0.1)$ of cell lines and treatment groups following $2 \mathrm{HF}$ treatment are presented in Supplementary Figure 1A and 1B. Read alignment statistics are provided in Supplementary Table 2. We further analyzed the statistically significant differences in gene expression (fold change $\leq 0.5$ and $\geq 1.5$ with $p$ $\leq 0.05$ ) using Ingenuity Pathway Analysis (Ingenuity systems, CA). The differential gene expression heatmap of $2 \mathrm{HF}$ treated and control groups showed a strong reversal of gene expression pattern in MCF7, MDA-MB-231 and SKBR3 BC cells while minimal impact was observed on the gene expression pattern of MCF10A normal breast epithelial cells (Figure 2D). The 2HF treatment led to statistically significant up regulation of 3372 genes and down regulation of 4013 genes in SKBR3 cells, up regulation of 2578 genes and down regulation of 3694 genes in MCF7 cells, and up regulation of 1316 genes and down regulation of 1370 genes in MDA-MB-231 cells. On the other hand, $2 \mathrm{HF}$ had modest effect in MCF10A cells as evident by up regulation of 52 genes and down regulation of 15 genes (Figure 2E). The Venn diagram showing the overlapping up regulated and down regulated genes is presented in Supplementary Figure 1C and $1 \mathrm{D}$, respectively. The complete lists of differentially expressed genes following $2 \mathrm{HF}$ treatment in MCF10A,
MCF7, MDA-MB-231 and SKBR3 cells are provided in Supplementary Tables 3-6. The box plot showing the statistical significance of $2 \mathrm{HF}$ induced differential gene expression is presented in Figure 2F.

\section{Regulation of critical survival, metastatic and differentiation genes by $2 \mathrm{HF}$ in breast cancer cells}

The 2HF treatment led to significant changes in the expression of a number of genes with critical functional role in the incidence, progression and therapy-resistance of BC (Supplementary Table 7). AFAP1L2/XB130 is an adaptor protein that is associated with multiple tyrosine kinase signaling transduced through the PI3K/Akt pathway and regulates cell invasion and motility [22]. 2HF treatment led to strong down-regulation of AFAP1L2 in $\mathrm{ER}^{+} \mathrm{MCF} 7$ cells. Carbonic anhydrase 9 (CA9) is involved in hypoxic survival of tumor cells and mediates resistance to both adjuvant chemotherapy and endocrine therapy in BC [23]. $2 \mathrm{HF}$ treatment led to a greater decrease in the levels of CA9 expression in MDA-MB-231 triple negative BC cells as compared to MCF7 and SKBR3 cells (Supplementary Table 7). The chloride intracellular channel protein 3 (CLIC3) is associated with tumor progression through its glutathione-dependent oxidoreductase activity [24]. The CLIC3 expression is associated with poor prognosis in early $\mathrm{BC}$ [25]. 2HF down-regulated the expression of CLIC3 with a predominant effect seen in $\mathrm{ER}^{+} \mathrm{MCF} 7$ and HER $2^{+}$SKBR3 cells as compared to triple-negative MDAMB-231 cells. The GABA type a receptor associated protein like 1 (GABARAPL1) is known to function as a tumor suppressor in BC by maintaining normal cellular metabolism [26]. 2HF treatment led to a strong up regulation of GABARAPL1 as in MCF7 and SKBR3 cells as compared to MDA-MB-231 cells. $2 \mathrm{HF}$ treatment also led to down-regulation of BC promoting miR210-HG in MCF7, MDA-MB-231 and SKBR3 cells [27].

We next assessed whether 2HF affects ER $\alpha$ and HER2 protein levels. 2HF decreased both ER $\alpha$ and HER2 protein levels in a concentration dependent manner in $\mathrm{ER}^{+} \mathrm{MCF} 7$ and HER2 ${ }^{+}$SKBR3 BC cells, respectively (Supplementary Figure 2A and 2B). An ongoing clinical trial (NCT00338728) is investigating the combination of letrozole, an aromatase inhibitor which decreases the 
levels of estrogen, and imatinib mesylate in hormonesensitive and advanced BC. As $2 \mathrm{HF}$ directly binds to ER $\alpha$, we further assessed the efficacy of $2 \mathrm{HF}$ on cell survival in combination with imatinib mesylate (Gleevec). The 25 and $50 \mu \mathrm{M} 2 \mathrm{HF}$ treatment significantly enhanced efficacy of 5 and $10 \mu \mathrm{M}$ imatinib mesylate in $\mathrm{ER}^{+} \mathrm{MCF} 7$ cells, a finding which indicated the ability of $2 \mathrm{HF}$ to sensitize $\mathrm{BC}$ cells to imatinib mesylate therapy (Supplementary Figure $2 \mathrm{C}$ ). We further confirmed $2 \mathrm{HF}$ induced gene expression changes by qRT-PCR (Supplementary Figure 2D-2F). The miR-22, a tumor suppressor miRNA and JMY, a P300 dependent activator of p53, were significantly increased in MCF7, MDA-MB-231 and SKBR3 cells [28, 29]. MiR-22 is also known to inhibit the function of ER $\alpha$ in $\mathrm{BC}$ [29]. ITGB6 is a prognostic marker associated with breast tumor progression [30]. We observed a downregulation of ITGB6 in $2 \mathrm{HF}$ treated HER2 ${ }^{+}$SKBR3 and triple-negative MDA-MB-231 cells (Supplementary Figure 2E and 2F).

\section{Ingenuity pathway analyses (IPA) of differentially regulated gene networks}

We further conducted IPA analyses to assess the significance of $2 \mathrm{HF}$ induced differential gene expression in regulating cellular signaling networks. The Supplementary Tables 8-11 provide information on all the upstream molecules differentially regulated following $2 \mathrm{HF}$ treatment in MCF10A normal breast epithelial and MCF7, MDA-MB-231 and SKBR3 BC cells. The differentially regulated top canonical pathways are presented in Supplementary Figure 3-6.

$2 \mathrm{HF}$ treatment led to inhibition of estrogen network in $\mathrm{ER}^{+}$MCF7 cells ( $\mathrm{z}$ score: -2.363 and $p$ : $5.4 \times 10^{-5}$ ) (Figure 3A). Expression of target genes like TGF $\beta 1$, BCL2, and TERT, which are up-regulated by estrogen-receptor, was decreased while expression of genes COL4A1 and RGS2, which are down-regulated by estrogen-receptor, was increased following $2 \mathrm{HF}$ treatment in MCF7 cells
A

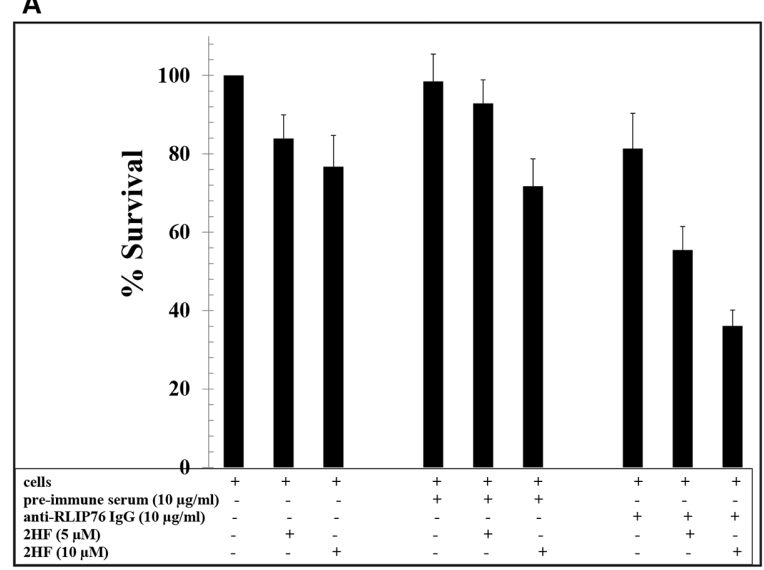

C

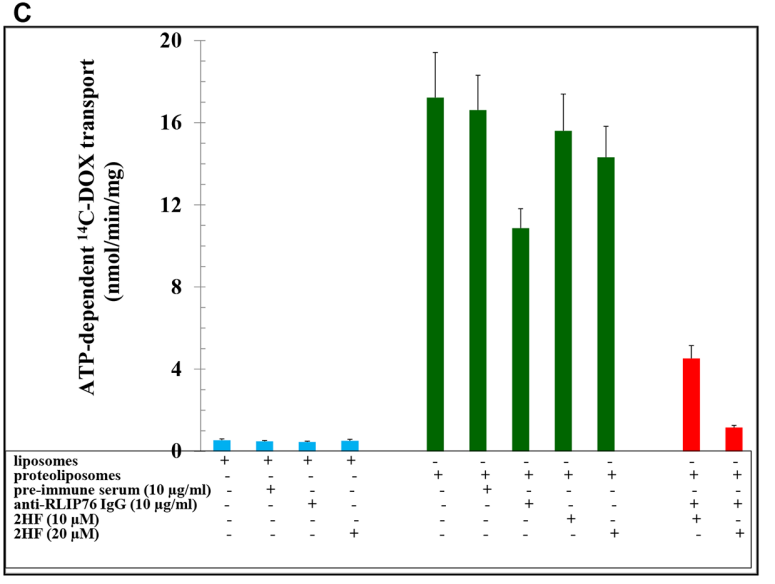

B

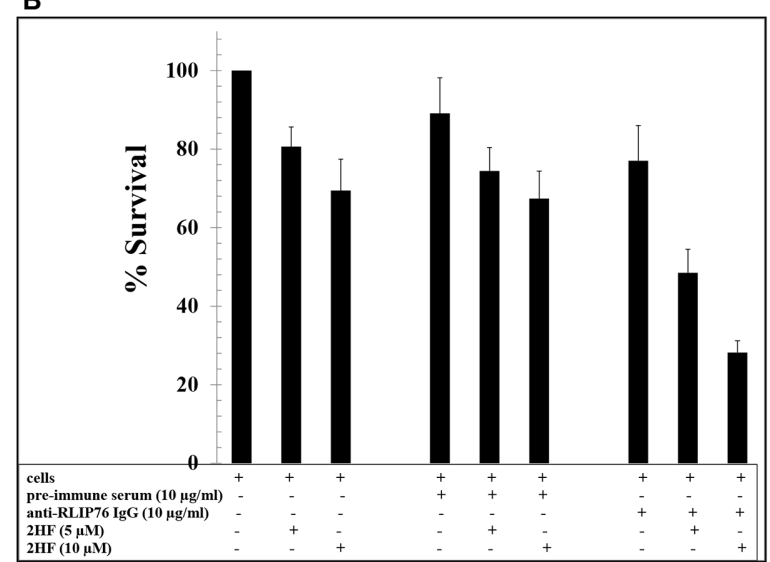

D

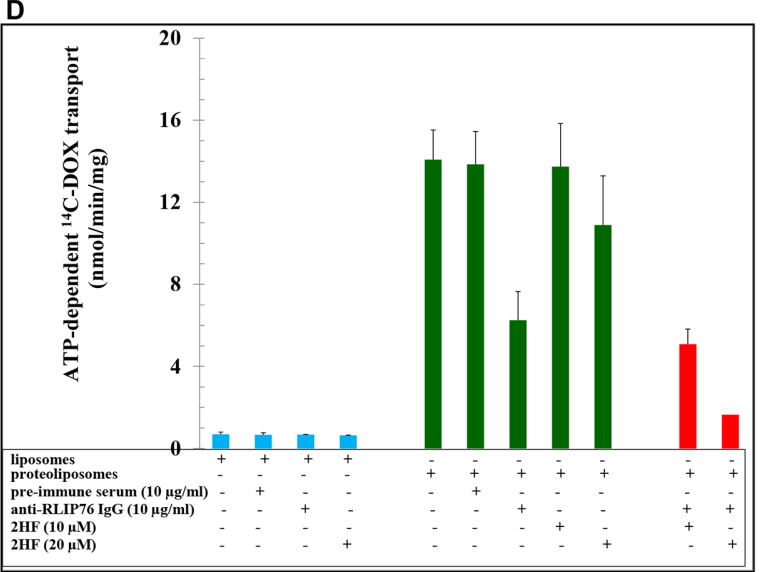

Figure 1: Effect of 2HF alone and in combination with RLIP76 inhibition in breast cancer survival and drug-resistance. (A-B) The effects of anti-RLIP76 IgG $(10 \mu \mathrm{g} / \mathrm{ml}$ conc.) and 2HF (5 and $10 \mu \mathrm{M}$ conc.) and their combination on the survival of MCF7 (A) and MDA-MB-231 (B) cells conducted using MTT assay. (C-D) Effects of anti-RLIP76 IgG (10 $\mu \mathrm{g} / \mathrm{ml})$ and $2 \mathrm{HF}(10$ and $20 \mu \mathrm{M})$ and their combination on the transport of ${ }^{14} \mathrm{C}$-DOX in purified reconstituted vesicles prepared from MCF7 (C) and MDA-MB-231 (D) cells performed by rapid-filtration technique using $250 \mathrm{ng}$ RLIP76 protein per $30 \mu \mathrm{l}$ reaction mixture. 
A

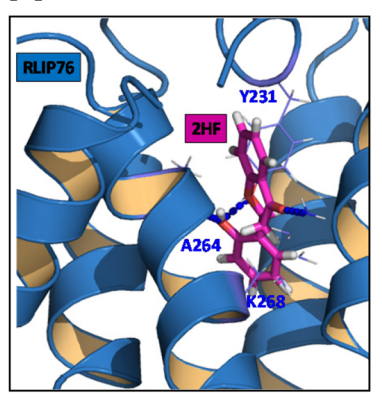

Color Key

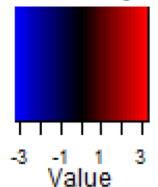

D $\quad{ }^{-3}$ Value $^{-1}$
B
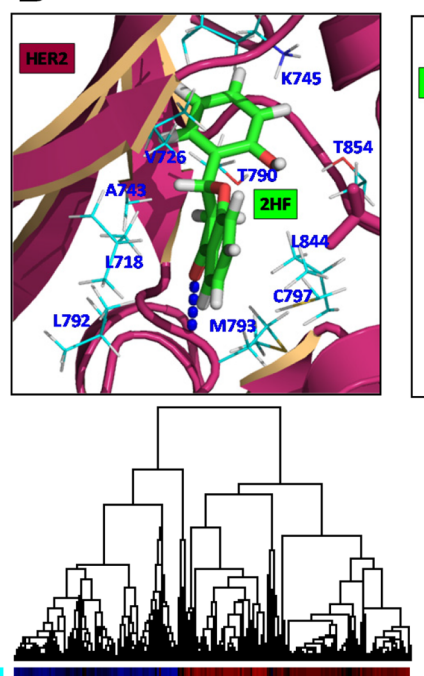

C

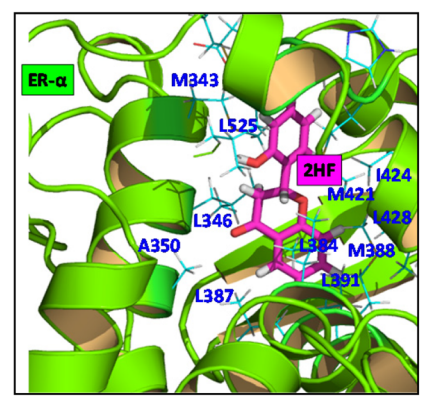

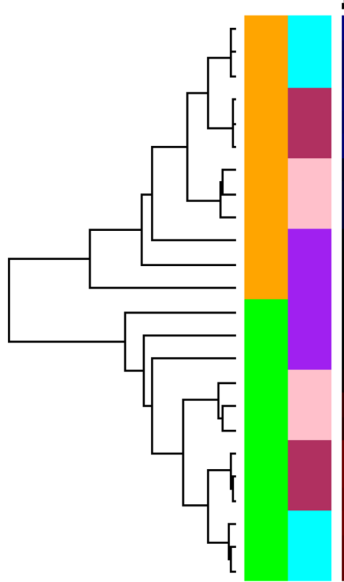

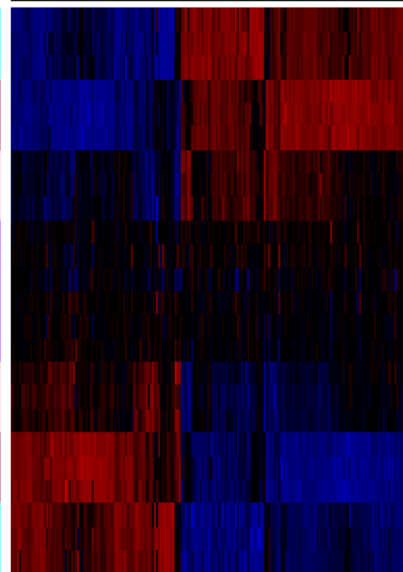

$=2 r=$

- MCFioA

MDAMEZ3

- SKBF3

Mcre

ncercis

sken 3 Ca

scrasca

SKBnsc1

SKBR3.C3

MDAME231C3
MOAME231C2

MOAME231C

MCF10AC3

MCF10RC2

MCF1OACA

MCE10A SAFE1

MCF10M SMF2

MOAMEST OHF

MDAMEZZ ATF 3

MOAME231. 2HF.1

MOAUEZS1 2HF2

SKEES 2MF3

SKER3 SNF1

SKER3 SMF2

MCF7 2-H.1

Mor7atis

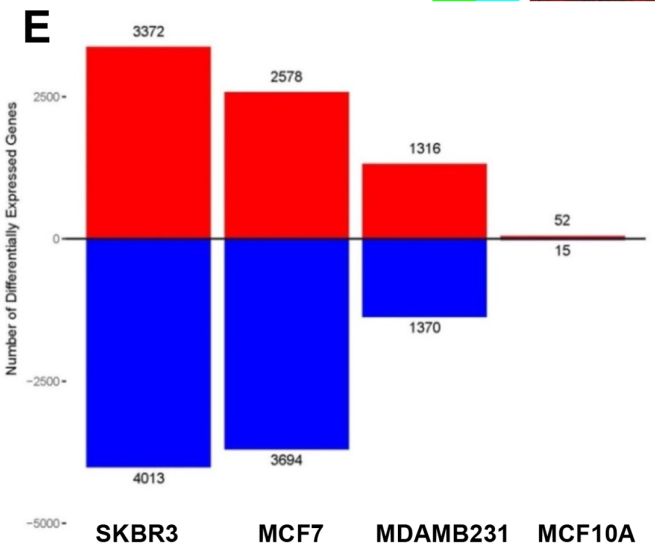

F

ANOVA $p$-value $=0$

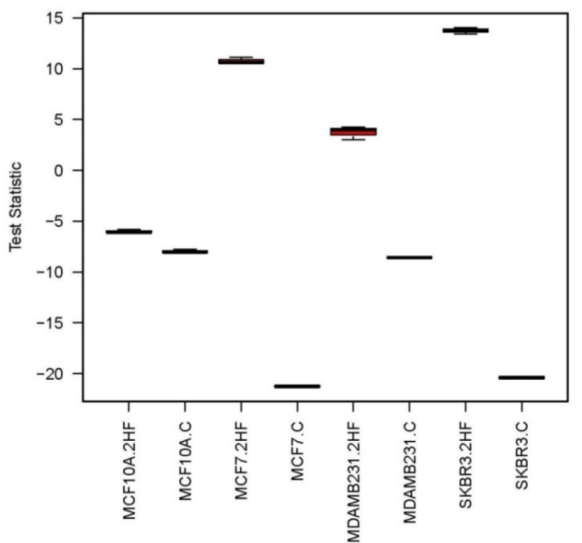

Figure 2: Docking of 2HF to RLIP76, ER $\alpha$ and HER2 and Effect on global gene expression in breast cancer cells. The high Glide XP docking scores of 2HF implies that 2HF has high binding energy in complex with the proteins RLIP76, HER2 and ESR1. (A) 2HF forms a hydrogen bond network with the ligand (DNP-SG)-binding site of RLIP76 via $\mathrm{Y}^{231}, \mathrm{~K}^{268}$ and $\mathrm{A}^{264}$ residues at a docking score of $-10.5 \mathrm{kcal} / \mathrm{mol}$. (B) $2 \mathrm{HF}$ also prefers binding at the ATP-binding pocket of HER2 forming hydrogen bond to $\mathrm{M}^{793}$ at a docking score of $-10.2 \mathrm{kcal} / \mathrm{mol}$. (C) $2 \mathrm{HF}$ docks to $\mathrm{ER} \alpha$ at the ligand-binding site through hydrophobic interactions at a docking score of $-9.7 \mathrm{kcal} / \mathrm{mol}$. (D) Heatmap showing a major reversal of gene expression pattern in MCF7, MDA-MB-231 and SKBR3 cells with minimal impact on MCF10A normal breast epithelial cells. (E) Bar diagram showing number of differentially expressed genes in normal breast epithelial and BC cells. (F) Box-plot diagram showing the statistical significance of $2 \mathrm{HF}$ induced differential gene expression in normal breast epithelial and $\mathrm{BC}$ cells. 


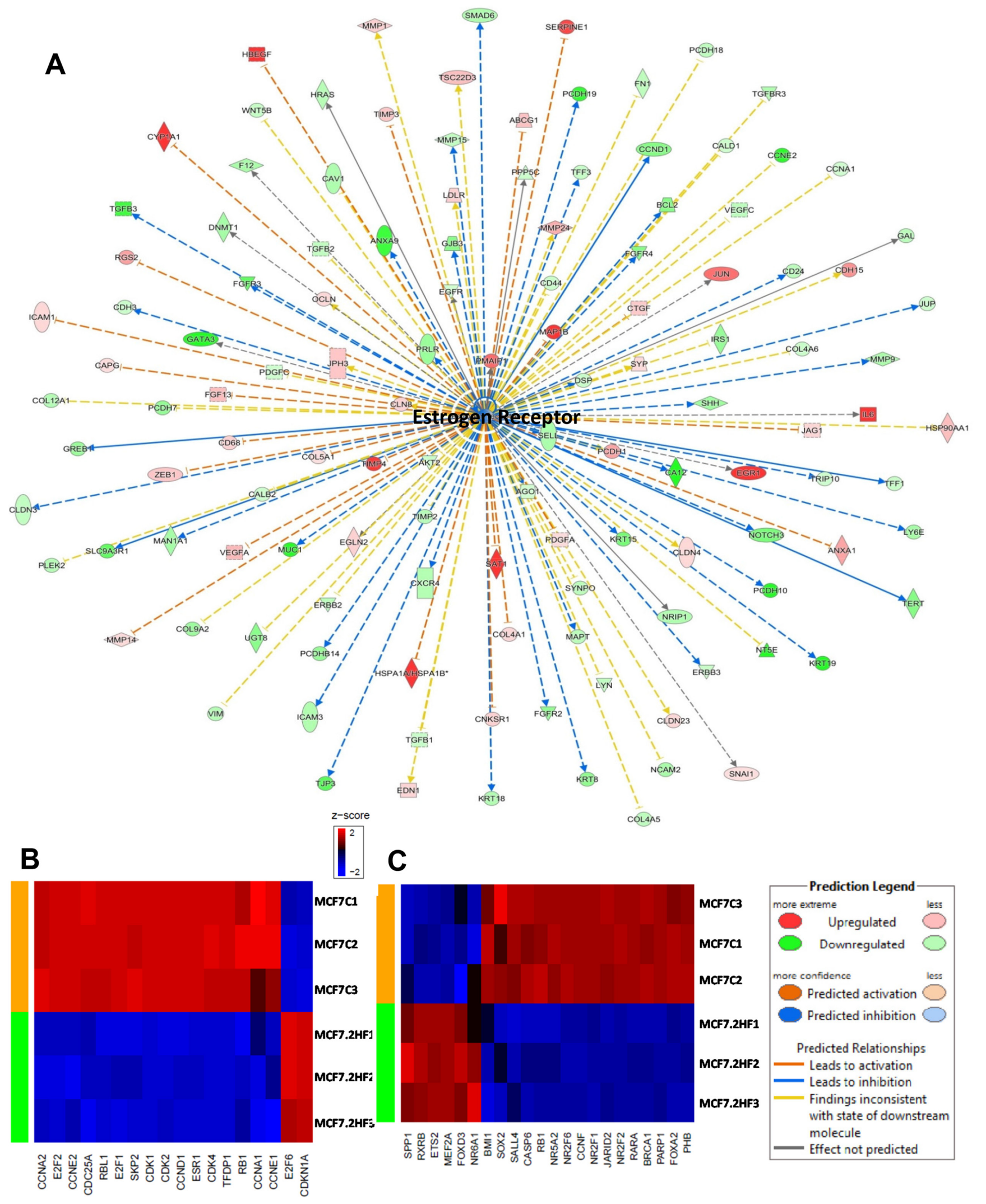

Figure 3: Effect of 2HF induced gene expression changes in ER+ MCF7 breast cancer cells. (A) Ingenuity Pathway Analyses (IPA) revealing the differentially expressed ER network genes in ER ${ }^{+}$MCF7 cells. (B) Heatmap showing 2HF induced differential gene expression in "Estrogen mediated s-phase entry canonical pathway" in MCF7 cells. (C) Heatmap showing 2HF induced differential gene expression in "Role of Oct4 in Mammalian Embryonic Stem cell pluripotency pathway" in MCF7 cells. 
(Figure 3A). In addition, 2HF treatment led to inhibition of estrogen-mediated S-phase entry canonical pathway in MCF7 cells (Figure 3B). Along with ESR1/ER $\alpha$ network, estrogen-mediated canonical pathway genes like CCNA2, CCNE2, E2F1, CDK1, CDK2 and CDK4 were down regulated in MCF7 cells (Figure 3B, $p$ : 9.65×10-4). E2F6 is known to be a dominant negative inhibitor of the $\mathrm{E} 2 \mathrm{~F}$ family of transcription factors while CDKN1A/p21 is a p53 induced negative inhibitor of cell cycle $[31,32]$. $2 \mathrm{HF}$ treatment led to up regulation of E2F6 and CDKN1A (Figure 3B). In addition, Oct4 canonical pathway was strongly inhibited along with down-regulation of stem cell pluripotency regulatory genes including SOX2, JARID2, and $\mathrm{PHB}$ following $2 \mathrm{HF}$ treatment in $\mathrm{ER}^{+} \mathrm{MCF} 7$ cells (Figure $3 \mathrm{C}, p$ : 0.02). The ATP-P2RY2- $\beta$-catenin pathway is known to promote invasion and metastases [33]. 2HF treatment down-regulated the P2RY2 purinergic receptor signaling pathway in MCF7 cells (Supplementary Figure 7). Sphingosine-1-phosphate is elevated in BC and plays a major role via phospholipase C (PLC) and RAS induced invasion [34]. The sphingosine-1-phosphate network was down-regulated by $2 \mathrm{HF}$ treatment in $\mathrm{ER}^{+} \mathrm{MCF} 7$ cells (Supplementary Table 7, Supplementary Figure 8).

SOX4 promotes PI3K/Akt signaling along with mediating TGF $\beta$ induced epithelial-mesenchymal transition (EMT) in BC cells [35]. The expression of CDH11 is increased in early stage and basal like BCs and mediates stem cell fate decisions [36]. 2HF treatment down-regulated SOX4 and CDH11 networks in MDAMB-231 cells (Figure 4A, z score: -2.2 and $p: 7.19 \times 10^{-5}$ ) and Figure 4B, z score: -2.33 and $p$ : 0.01). The expression of IL24 tumor suppressor is lost in basal like BC [37]. 2HF treatment activated the IL24 network functions in basal like triple-negative MDA-MB-231 BC cells (Figure 4C, z score: 2.76 and $p$ : 0.02). Macropinocytosis is an actin driven endocytic process that is known to regulate EGF, PDGF and HGF signaling [38]. 2HF treatment inhibited the macropinocytosis pathway in triple-negative MDAMB-231 cells with a marked decrease in the expression of macropinocytosis associated genes including RRAS, RAC1, CDC42, and ARF6 (Figure 4D, $p$ : 0.004). The planar cell polarity (PCP) pathway involving WNTs and frizzled (FZD) receptors controls the distribution of cells within a plane that in turn influences the invasiveness and migration of $\mathrm{BC}$ cells [39]. 2HF treatment led to down-regulation of PCP pathway (Figure 4E, $p$ : 0.016). The down-regulation of PCP pathway in MDA-MB-231 cells was characterized by decreased expression of FZD1, FZD4 and FZD8 receptors, LGR4, syndecans 3 and 4 (SDC3 and SDC4), which are associated with WNT signaling (Figure 4E \& Supplementary Figure 9). Further, $2 \mathrm{HF}$ treatment induced a down-regulation of multiple tubulin isoforms 1, 2, 3 and 4 via down-regulation of 14-33 signaling while also inhibiting IGF1 signaling pathway, which is activated in triple-negative BCs (Supplementary Figures 10 and 11) [40, 41].
In $\mathrm{HER}^{+}$SKBR3 cells, 2HF treatment led to decreased expression of HER2 and down-regulation of HER2 signaling network (Figure 5A, z score: - 4.798 and $p: 2.34 \times 10^{-8}$ ). Polo-Like kinases (PLK) are serine/ threonine kinases that regulate multiple functions during cell cycle [42]. 2HF treatment led to inhibition of pololike kinase mediated mitotic activity pathway in HER2 ${ }^{+}$ SKBR3 cells (Figure 5B \& Supplementary Figure 12, $p$ : $\left.5.88 \times 10^{-4}\right)$. The AURKB expression is correlated with strong proliferative index and chemo-resistance in $\mathrm{BC}$ [43]. 2HF inhibited AURKB network in HER2 ${ }^{+}$SKBR3 cells (Figure 5C, p: 0.007). Sphingosine-1-phosphate signaling mediates phospholipase $\mathrm{C}$ (PLC) and RAS induced invasion [34]. 2HF treatment also led to inhibition of Sphingosine-1-phosphate signaling in HER2 ${ }^{+}$SKBR3 cells (Supplementary Figure 13).

\section{HF treatment regulates critical genes of clinical- prognostic significance}

MammaPrint is a FDA approved test containing a panel of genes to aid therapeutic decisions in women of all ages with both $\mathrm{ER}^{+}$and $\mathrm{ER}^{-} \mathrm{BCs}$. List of differentially regulated MammaPrint genes following $2 \mathrm{HF}$ treatment in MCF7, MDA-MB-231 and SKBR3 cells are presented in Supplementary Table 12. 2HF treatment led to downregulation of MammaPrint genes CCNE2, MCM6, DCK, LPCAT1, DTL, GNAZ, ECI2, MELK, NMU, NUSAP1 and EGLN1 in BC cells. Transforming Growth Factor beta 3 (TGF $\beta 3$ ) is expressed at high levels in primary $\mathrm{BC}$ [44]. TGF $\beta 3$ is known to act as a tumor promoter in triple-negative $\mathrm{BCs}$ [45]. Both, TGF $\beta 3$ and TGF $\beta$ receptor 3 (TGF $\beta$ R3) were down-regulated in $2 \mathrm{HF}$ treated MCF7 cells. While TGF $\beta 3$ changes were undetected, TGF $\beta$ R3 was down-regulated by 5 folds in MDA-MB-231cell lines (Supplementary Table 5). Thus, down-regulation of TGF $\beta 3$ pathway was common to both $2 \mathrm{HF}$ treated $\mathrm{ER}^{+}$ MCF7 and triple-negative MDA-MB-231 cells.

The top upstream changes that were differentially regulated following $2 \mathrm{HF}$ treatment were TP53 activation and $\beta$-estradiol inhibition in $\mathrm{ER}^{+} \mathrm{MCF} 7$ cells, TGF $\beta 1$ inhibition in triple-negative MDA-MB-231 cells, and TP53 activation, E2F1 and RABL6 inhibition in HER2 ${ }^{+}$ SKBR3 cells (Figure 6A). The regulation of MammaPrint genes has been predicted to be due to 5 upstream nodes including TP53, RB1, MYC, JUN and CDKN2A [46]. In this regard, using IPA, we further analyzed the differences in $2 \mathrm{HF}$ induced fold changes of MammaPrint genes for each of the respective cell lines (Figure 6B). We did not observe a particular pattern of MammaPrint upstream nodes in triple-negative MDA-MB-231 cells. IPA revealed that the $2 \mathrm{HF}$ induced MammaPrint gene expression is regulated by down-regulation of EPAS1, MYC, HIF1A and PTGER2 and by up regulation of CDKN2A and let-7 networks in $\mathrm{ER}^{+} \mathrm{MCF} 7$ cells. Down-regulation of ERBB2/ HER2 and PTGER2, and up regulation of let-7 networks 


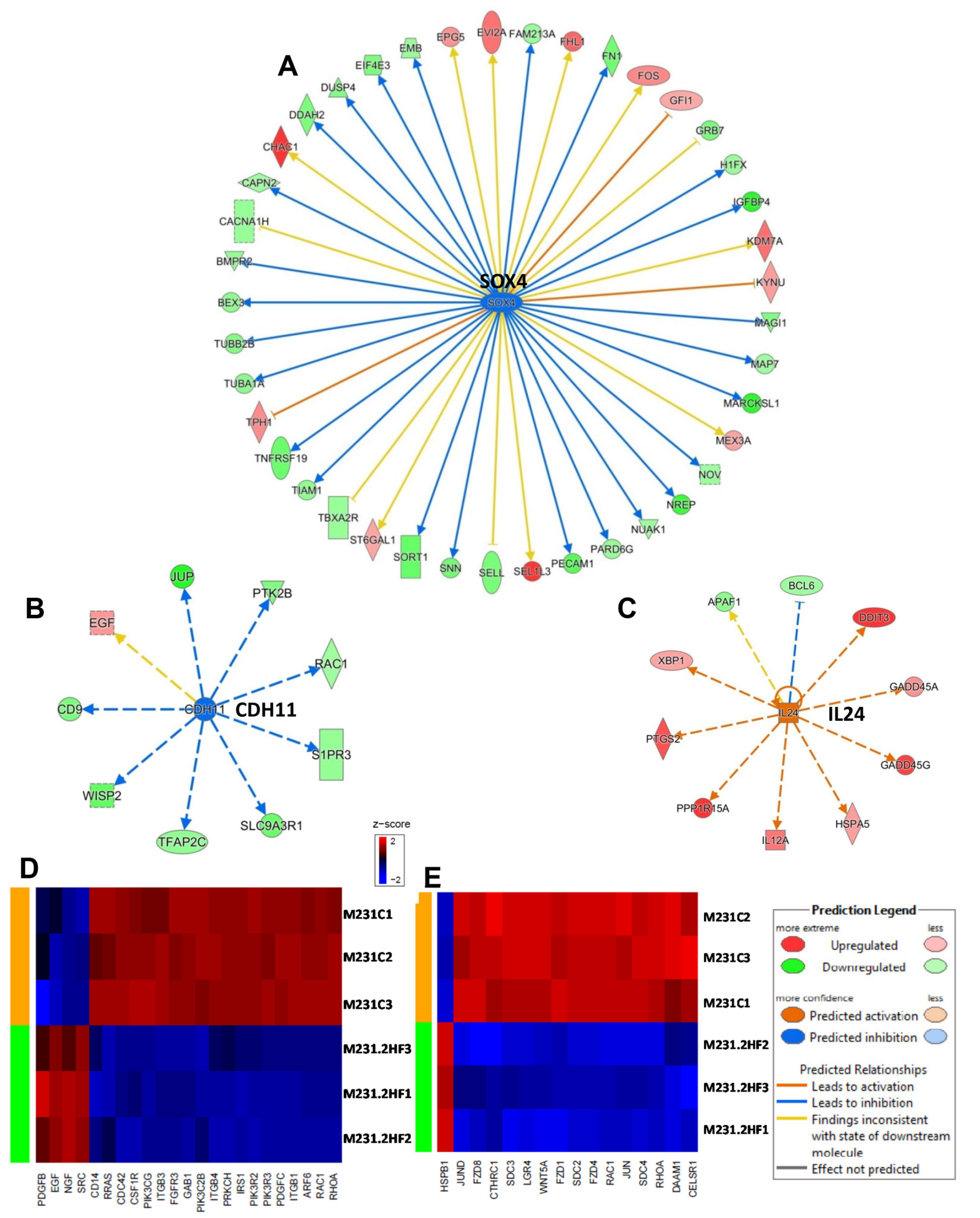

Figure 4: Effect of $2 \mathrm{HF}$ induced gene expression changes in triple-negative MDA-MB-231 breast cancer cells. (A) Ingenuity Pathway Analyses (IPA) revealing the differentially expressed SOX4 network genes in triple-negative MDA-MB-231 cells. (B) IPA revealing the differentially expressed CDH11 network genes in MDA-MB-231 cells. (C) IPA revealing the differentially expressed IL24 network genes in MDA-MB-231 cells. (D) Heatmap showing 2HF induced differential gene expression in "Macropinocytosis signaling canonical pathway" in MDA-MB-231 cells. (E) Heatmap showing 2HF induced differential gene expression in "Planar cell polarity (PCP) pathway" in MDA-MB-231 cells. 

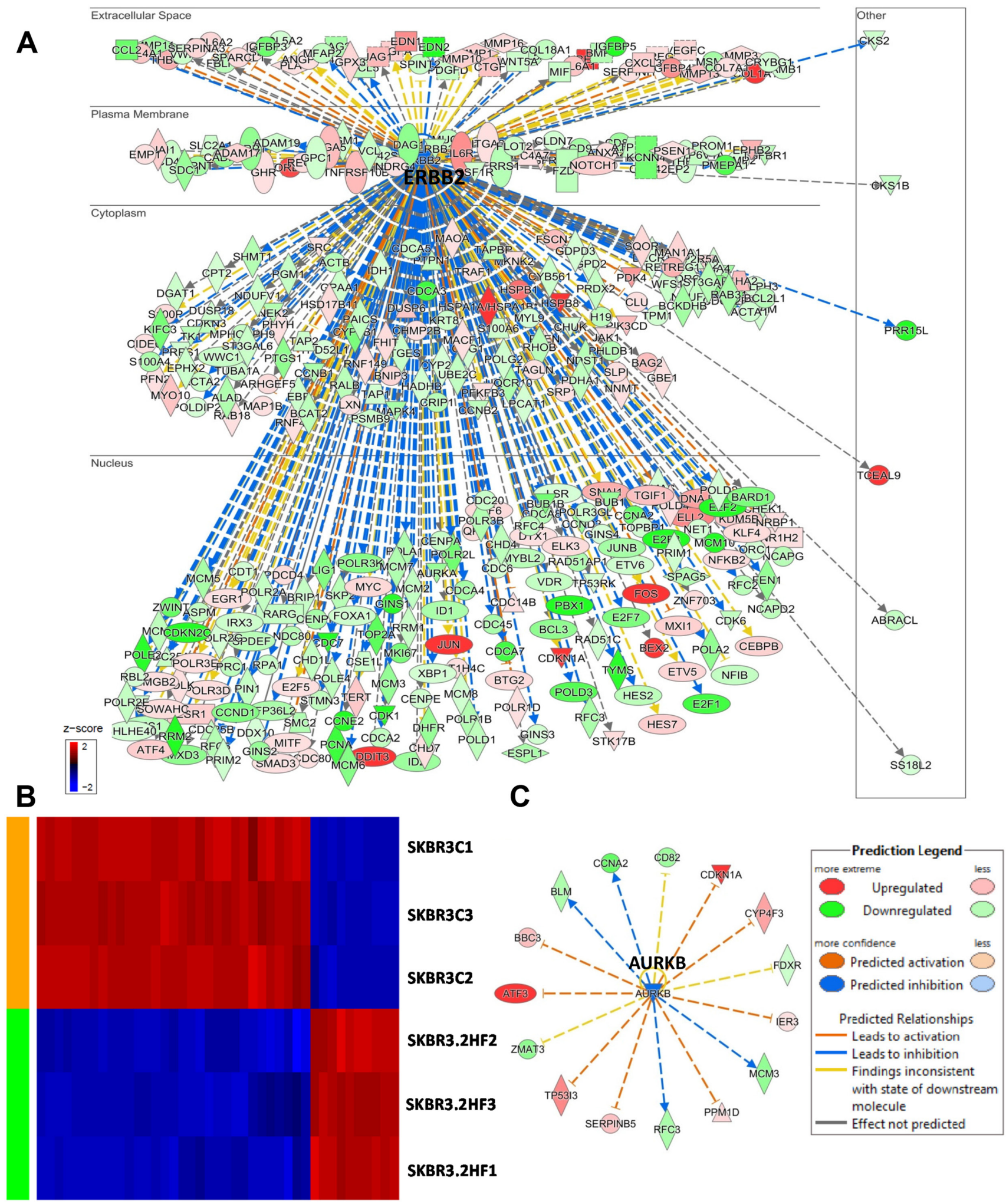

SKBR3.2HF1

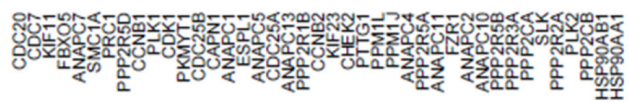

Figure 5: Effect of 2HF induced gene expression changes in HER2+ SKBR3 breast cancer cells. (A) Ingenuity Pathway Analyses (IPA) revealing the differentially expressed HER2 network genes in HER2 ${ }^{+}$SKBR3 cells. (B) Heatmap showing 2 HF induced differential gene expression in "Mitotic Role of Polo-Like kinase pathway" in SKBR3 cells. (C) IPA revealing the differentially expressed AURKB network genes in SKBR3 cells. 

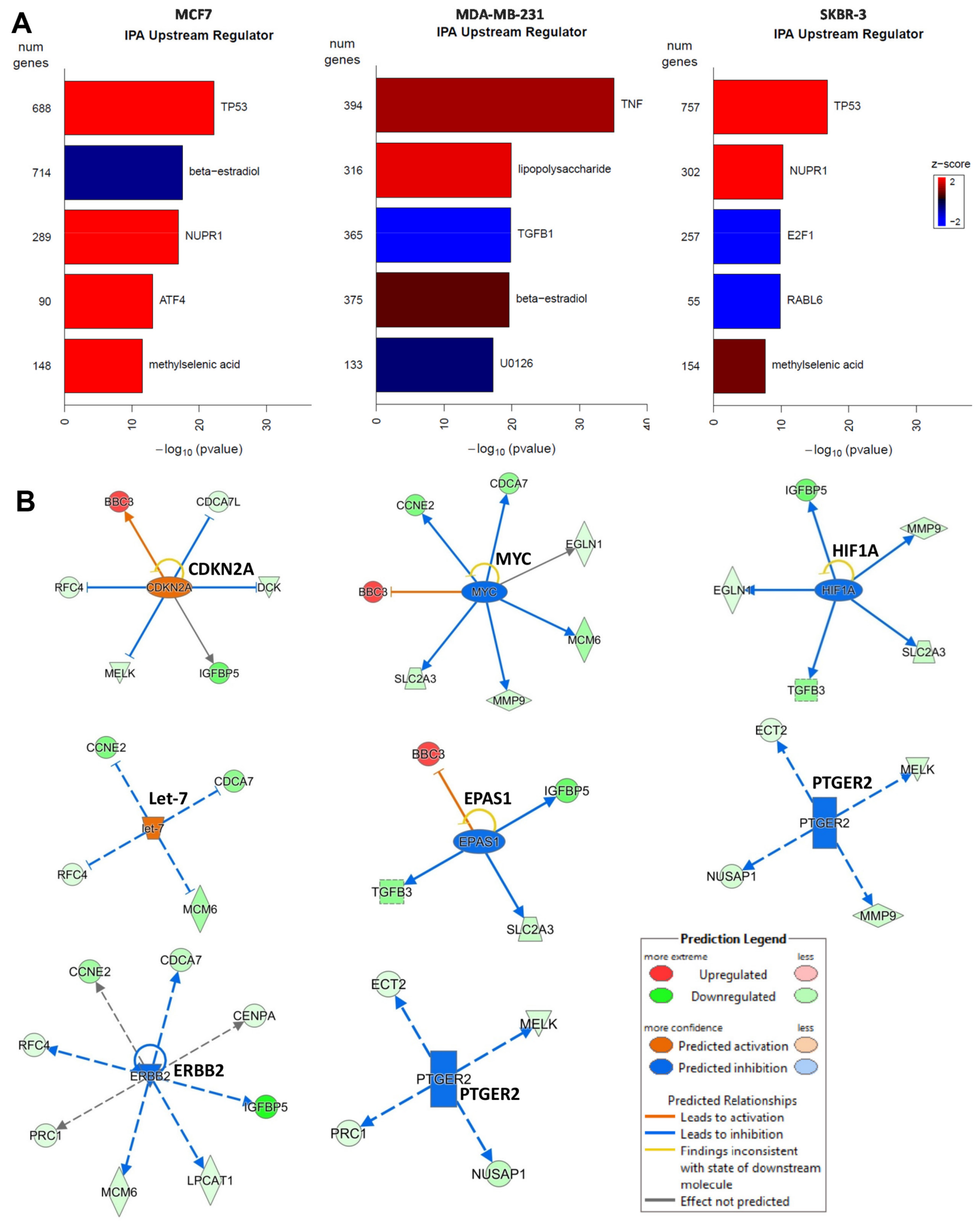

Figure 6: Effect of $2 \mathrm{HF}$ on critical upstream regulators in breast cancer cells. (A) Ingenuity Pathway Analyses (IPA) revealing the differential regulation of key upstream targets including TP53, estradiol, TGF31, E2F1, RABL6 in BC cells. (B) 2HF induced regulation of critical nodes like CDKN2A, MYC, HIF1A, let-7, EPAS1, PTGER2 and ERBB2 that in turn regulate a number of MammaPrint clinicalprognostic gene panel. 
contributed to many of the changes in $2 \mathrm{HF}$ induced expression of MammaPrint genes in HER2 ${ }^{+}$SKBR3 cells. These findings, given the known ability of $2 \mathrm{HF}$ to decrease RLIP76 levels, when taken in the context of the role of RLIP76 in receptor-ligand signaling mediated by CDE and in pathogenesis of metabolic syndrome, provide promising evidence for $2 \mathrm{HF}$ and RLIP76 focused interventions for targeting both BC risk and progression [15, 47-48].

\section{DISCUSSION}

Characterization of novel therapeutic molecules capable of targeting critical mechanistic nodes in BC is a significant focus of translational cancer research. RLIP76 is a multi-functional protein: a major and multi-specific GS-E transporter of MAP that regulates apoptotic resistance via mediating efflux of products of lipid peroxidation and facilitates tumor drug-resistance by mediating the transport of GS-Es of chemotherapy drugs [6-8]. RLIP76 is a rac and ral effector and has been shown to be an essential factor in determining the invasive and metastatic aggressiveness of cancers [49-51]. Importantly, RLIP76 has been shown to be an essential prerequisite for epithelial carcinogenesis [7]. The expression of RLIP76 is up-regulated in multiple cancers while inhibiting either the function or expression of RLIP76 causes regression of established xenografts of skin, lung, pancreatic, kidney and colon cancers [8-10]. Our studies indicate that RLIP76 inhibition in combination with $2 \mathrm{HF}$ could be directly relevant to therapeutic management of $\mathrm{BC}$. RLIP76 inhibition along with $2 \mathrm{HF}$ administration is also a translationally significant chemoprevention strategy that needs to be further considered as RLIP76 knockout mice survive full life-span without any overt toxicity.

Multiple findings from this study provide a highly significant and directly relevant mechanistic evidence for further development and clinical testing of $2 \mathrm{HF}$ in $\mathrm{BC}$. First, 2HF shows docking to ligand (DNP-SG)-binding site of RLIP76, ATP binding site of HER2 and ligandbinding site of ER $\alpha$. Second, $2 \mathrm{HF}$ decreases the levels of ER $\alpha$, HER2 and potentiates the effects of RLIP76 antibody in both inhibiting $\mathrm{BC}$ cell survival and in doxorubicin transport studies. Third, 2HF induces strong regulatory effects at gene expression levels in all the major types of BC cells. In support of our docking model, the gene expression studies confirmed a comprehensive down-regulation of ER $\alpha$ and HER2 networks. Fourth, 2HF was effective in triple-negative MDA-MB-231 cells where it induced significant inhibition of macropinocytosis and Planar Cell Polarity Pathway (PCP) signaling, a significant finding given the established role of RLIP76 in regulating endocytosis of ligand-receptor complexes and Wnt- $\beta$ catenin signaling. Fifth, the translational relevance of $2 \mathrm{HF}$ was further confirmed by its characteristic downregulation of critical MammaPrint genes including CCNE2, LPCAT1, MCM6, DCK, GNAZ, ECI2, DTL,
MELK, NUSAP, NMU, 1and EGLN1 in MCF7, SKBR3 and MDA-MB-231 BC cells. In addition, $2 \mathrm{HF}$ regulated critical upstream regulators of MammaPrint genes including TP53, MYC and CDKN2A. Given the positive association of obesity with $\mathrm{BC}$ incidence and progression in post-menopausal women and the known ability of flavonoids to decrease pro-inflammatory state induced by obesity, $2 \mathrm{HF}$ administration may also provide further translationally relevant benefits for $\mathrm{BC}$ risk reduction [52]. These factors provide collective basis for the strong chemopreventive and therapeutic potential of $2 \mathrm{HF}$ in $\mathrm{BC}$.

In conclusion, the mechanistic spectrum of the effects of 2HF on RLIP76-mediated DOX transport, ER $\alpha$, HER2, and MammaPrint prognostic gene networks collectively provides a strong rationale for translational development and clinical testing of 2HF and RLIP76 based interventions for $\mathrm{BC}$ prevention and therapy.

\section{MATERIALS AND METHODS}

\section{Reagents and cell lines}

2HF (purity $\sim 99 \%$ ), Horseradish peroxidase (HRP)-conjugated anti-mouse, and anti-rabbit secondary antibodies, and MTT were purchased from SigmaAldrich, St. Louis, MO. The primary antibodies were purchased from Thermo Fisher, Abcam and Cell Signaling Technologies. ${ }^{14} \mathrm{C}$-DOX (specific activity $58 \mathrm{mCi} / \mathrm{mmol}$ ) was purchased from NEN Life Sciences (Boston, MA). Human breast untransformed (MCF10A) and cancer (MCF7, MDA-MB-231 and SKBR3) cell lines were purchased from the American Type Culture Collection (ATCC, Manassas, VA). The authentication of cell lines was done by analyzing fifteen different human short tandem repeat (STR) at Genomic Core of the City of Hope, Duarte, CA. All the cells were also tested for Mycoplasma once every 3 months.

\section{Ethics statement}

No animals and human subjects are involved in the present study.

\section{Drug sensitivity (MTT) assay}

Cell density measurements were performed using a hemocytometer to count viable cells resistant to staining with trypan blue. Approximately 10,000 cells were plated into each well of 96-well flat-bottomed micro-titer plates. After $12 \mathrm{~h}$ incubation at $37^{\circ} \mathrm{C}$, medium containing $2 \mathrm{HF}$ (ranging 0-100 $\mu \mathrm{M}$ ) were added to the cells. After $48 \mathrm{~h}$ incubation, $20 \mu \mathrm{l}$ of $5 \mathrm{mg} / \mathrm{ml}$ MTT were introduced to each well and incubated for $2 \mathrm{~h}$. The plates were centrifuged and medium was decanted. Cells were subsequently dissolved in $100 \mu \mathrm{l}$ DMSO with gentle shaking for $2 \mathrm{~h}$ at room temperature, followed by measurement of $\mathrm{OD}_{570}$. 
Eight replicate wells were used at each point in each of three separate measurements.

\section{Computational and docking studies}

Computational analyses of Lipinski Rule of 5 were conducted using TargetNet (http:/targetnet.scbdd.com/ calcnet/index_rule/). The binding models of $2 \mathrm{HF}$ molecule in complex with RLIP76, HER2 and ER $\alpha$ were calculated by using Schordinger induce fit docking software and our in-house developed All-Around Docking (AAD) methodology [20, 21]. The three-dimensional protein structures were obtained from protein data bank (PDB) as PDB id 2MBG for RLIP76, 1XKK for HER2 and 3ERT for ER $\alpha$. AAD docking, which docks the small molecule on the whole surface of target protein to determine the best binding region, was carried out first to predict the binding pocket of $2 \mathrm{HF}$. Then induced fit docking, which allows side-chain of the pocket residues to be flexible for more accurate calculation, was used to determine the docking score by docking $2 \mathrm{HF}$ to the binding pocket predicted from AAD.

\section{Purification and reconstitution of purified RLIP76 into artificial liposomes}

DNPSG-affinity purification of RLIP76 from MCF7 and MDA-MB231 cells was carried out as described previously [18]. Purifications were monitored by measuring ATPase and transport activity. Purified RLIP76 from $\mathrm{BC}$ cells was dialyzed against reconstitution buffer (10 mM Tris-HCl, $\mathrm{pH} 7.4,4 \mathrm{mM} \mathrm{MgCl}, 1$ mM EGTA, $100 \mathrm{mM} \mathrm{KCl}, 40 \mathrm{mM}$ sucrose, $2.8 \mathrm{mM} \beta$-mercaptoethanol, $0.05 \mathrm{mM}$ BHT, and $0.025 \%$ polidocanol), and reconstituted into artificial asolectin-cholesterol liposomes. An aqueous emulsion of soybean asolectin (40 $\mathrm{mg} / \mathrm{ml})$ and cholesterol $(10 \mathrm{mg} / \mathrm{ml})$ was prepared in the reconstitution buffer by sonication, from which a $100 \mu \mathrm{l}$ aliquot was added to $0.9 \mathrm{ml}$ of dialyzed purified RLIP76 protein. After sonication of the resulting mixture for 30 $\mathrm{s}$ at $50 \mathrm{~W}, 200 \mathrm{mg}$ of SM-2 Bio-beads pre-equilibrated with reconstitution buffer (without polidocanol) were added to initiate vesiculation, and after $4 \mathrm{~h}$ incubation at $4{ }^{\circ} \mathrm{C}, \mathrm{SM}-2$ beads were removed by centrifugation at 3000 $\mathrm{x} \mathrm{g}$ and the vesicles (proteoliposomes) were collected. Control-liposomes were prepared using an equal amount of crude protein from E. coli not expressing RLIP76. The size of reconstituted vesicles was examined by electron microscopy and intra-vesicular volume was estimated by ${ }^{14} \mathrm{C}$-inulin trapping [19].

\section{Transport studies in RLIP76-proteoliposomes}

Transport studies of ${ }^{14} \mathrm{C}$-DOX in reconstituted vesicles were performed by rapid-filtration technique as described by us using $250 \mathrm{ng}$ protein per $30 \mu \mathrm{l}$ reaction mixture. ATP-dependent uptake of ${ }^{14} \mathrm{C}$-DOX (specific activity $8.5 \times 10^{4} \mathrm{cpm} / \mathrm{nmol}$, use $3.6 \mu \mathrm{M}$ final concentration) was determined by subtracting the radioactivity (cpm) of the control without ATP from that of the experimental containing ATP, and the transport of DOX was calculated in terms of $\mathrm{nmol} / \mathrm{min} / \mathrm{mg}$ protein. Liposomes prepared without addition of RLIP76 were used for controls. Each determination was performed in triplicate [6].

\section{Transport inhibition by $2 \mathrm{HF}$ and anti- RLIP76 IgG}

Purified reconstituted liposomes (250 ng protein/30 $\mu \mathrm{l}$ reaction mixture) were incubated separately with either 2HF (0-50 $\mu \mathrm{M}$ final concentration) or anti-RLIP76 $\operatorname{IgG}$ $(0-60 \mu \mathrm{g} / \mathrm{ml}$ final concentration) or both, for $30 \mathrm{~min}$ at room temperature. In one of the controls, IgG was excluded while the other control was treated with an equal amount of pre-immune IgG. After incubation, the ATPdependent transport of ${ }^{14} \mathrm{C}$-DOX was measured by using a 96 well-plate filtration manifold to separate the extravesicular drug from that taken up by the vesicles. Uptake was measured in parallel in RLIP76-proteoliposomes and control liposomes, in absence or presence of 2HF, antiRLIP76 IgG and $4 \mathrm{mM}$ ATP at a fixed time point of $5 \mathrm{~min}$, at $37^{\circ} \mathrm{C}[6]$.

\section{RNA isolation and sequencing}

The cells ( $3 \times 10^{5} /$ well in 6-well plates) were treated with $50 \mu \mathrm{M} 2 \mathrm{HF}$ or vehicle (DMSO) and RNA isolated 24 $\mathrm{h}$ post treatment. Three biological replicates were prepared for $2 \mathrm{HF}$ treatment as well as control untreated cells. After treatment, total RNA was prepared using RNeasy Mini Kit (Qiagen) according to the manufacturer's instructions, eluted in $50 \mu \mathrm{L}$ of RNase/DNase-free water, and initial concentration and purity assessed by NanoDrop ND1000 spectrophotometer (NanoDrop Technologies, Wilmington, DE). Prior to sequencing, RNA quality was also assessed by microfluidic capillary electrophoresis using an Agilent 2100 Bioanalyzer and the RNA 6000 Nano Chip kit (Agilent Technologies, Santa Clara, CA). Sequencing libraries were prepared with the TruSeq RNA Sample Prep Kit V2 (Illumina, San Diego, CA) according to manufacturer's protocol with minor modifications. Briefly, ribosomal RNA was removed from $500 \mathrm{ng}$ of total RNA using RiboZero kit (Illumina) and the resulting RNA was ethanol precipitated. Pellets were resuspended in $17 \mu \mathrm{l}$ of Elute/Prime/Fragment Mix (Illumina) and first-strand cDNA synthesis performed using DNA polymerase I and RNase H. cDNA was end repaired, 3' end adenylated, and universal adapter ligated followed by 10 cycles of PCR using Illumina PCR Primer Cocktail 
and Phusion DNA polymerase (Illumina). Libraries were purified with Agencourt AMPure XP beads, validated with Agilent Bioanalyzer 2100, and quantified with Qubit (Life Technologies). Libraries were sequenced on Illumina Hiseq 2500 with single end $40 \mathrm{bp}$ reads. Reads were aligned using TopHat (2.0.8b) to human genome hg19. Read alignment statistics are provided in Supplementary Tables 1 and 2 .

\section{RNA-seq and gene ontology}

Differential gene expression was identified from standard Partek workflow (Partek Genomics Suite v6.6, Partek, Inc) using ANOVA, with step-up FDR multiple testing correction $p$-value $<0.05$ and requiring a $>1.5 \mathrm{x}$ fold change between treatment and control samples. Gene ontology for the $24 \mathrm{~h} 2 \mathrm{HF}$ treatment up- or downregulated genes were analyzed for functional enrichment using the Database for Annotation, Visualization, and Integrated Discovery (DAVID, v6.7). For inclusion, terms required an EASE score of $p<0.005$. Fold-changes in gene expression between control and $24 \mathrm{~h} 2 \mathrm{HF}$ treatment were derived from the comparative $C T$ method with $\beta$-actin as an internal control. Correlation between the expression values detected by RNA-seq (normalized log2 RPKM fold-change) and qRT-PCR (mean fold change) for the 10 genes tested was estimated by calculating Spearman's Rho correlation in the Prism 6.0 software (GraphPad, San Diego, CA, USA). Mann-Whitney U-tests were used to assess statistical significance between time points (two-tailed, ${ }^{*} p<0.05$ ). The significance of differentially regulated genes was further analyzed by Ingenuity Pathway Analyses (IPA; Ingenuity Systems, CA). The statistically significant gene expression fold differences from $2 \mathrm{HF}$ and control samples for each of the cell lines were thoroughly analyzed using IPA. The differences in canonical pathways, upstream regulators and networks were analyzed using IPA along with further search for latest findings on key nodes of signaling regulators as relevant to pathogenesis and clinical prognosis of breast cancer.

\section{Quantitative real-time PCR (qRT-PCR) validation}

To confirm the results obtained from RNA-seq analysis, biologically significant up- and down-regulated genes at $24 \mathrm{~h}$ post $2 \mathrm{HF}$ treatment were selected and analyzed by qRT-PCR. First strand cDNA was prepared using the High Capacity cDNA Reverse Transcription Kit (Life Technologies). The primer pairs were purchased from Integrated DNA Technologies (San Diego, CA). The qRT-PCR was performed on three independent samples per treatment using the ABI-7500 Fast Real Time PCR system (Life Technologies) and Power SYBR Green master mix. After initial incubation for $2 \mathrm{~min}$ at $50{ }^{\circ} \mathrm{C}$, the
cDNA was denatured at $95{ }^{\circ} \mathrm{C}$ for $10 \mathrm{~min}$ followed by 40 cycles of PCR $\left(95^{\circ} \mathrm{C}\right.$ for $15 \mathrm{~s}, 60^{\circ} \mathrm{C}$ for $\left.60 \mathrm{~s}\right)$.

\section{Immunoblotting}

Supernatant proteins from control and $2 \mathrm{HF}$ treated cell lysates were resolved by sodium-dodecyl sulfate polyacrylamide gel electrophoresis and transferred onto polyvinylidene fluoride membrane. Change in the level of desired protein was determined by densitometric scanning of the immuno-reactive bands. Equal loading of proteins was confirmed by stripping and re-probing the membranes with $\beta$-actin antibodies.

\section{Statistical analysis}

All data were evaluated with a two-tailed unpaired student's $t$ test are expressed as the mean $\pm \mathrm{SD}$. The statistical significance of differences between control and treatment groups was determined by ANOVA followed by multiple comparison tests. Differences were considered statistically significant when z score was either above 2 or below -2 , and the $p$ value was less than 0.05 .

\section{Abbreviations}

AKT: protein kinase B (PKB), also known as AKT; pAMPK: phosphorylated form of AMP-activated protein kinase; BC: breast cancer; BCL2: B-cell CLL/lymphoma 2; CDE: clathrin-dependent endocytosis; $\mathrm{CDK}$ : cyclin dependent kinase; E2F1: E2F transcription factor 1; EGF: epidermal growth factor; EMT: epithelial mesenchymal transition; ER: estrogen receptor; EGFR: epidermal growth factor receptor; ERBB2: Erb-B2 receptor tyrosine kinase 2 or HER2; ERK: extracellular signal-regulated kinase; FDA: Food and Drug Administration; HBA-Hydrogen Bond Acceptors; HBD-Hydrogen Bond Donors; HER2: receptor tyrosine-protein kinase erbB-2; ITGA: integrinA; ITGB6: integrin beta 6; IGF: insulin growth factor; IPA: ingenuity pathway analyses; $\log \mathrm{P}$ - Partition Coefficient; miR: micro-RNA; MMP: matrix metallo proteinase; MRMolar Refractivity; PI3K: phosphoinositide-3 kinase; RLIP76: $76 \mathrm{kDa}$ a ral binding/ral-interacting protein, also known as RalBP1; TP53: tumor suppressor 53; TPSAtotal polar surface area; SOX4: SRY-Box 4; TGF $\beta 3$ : transforming growth factor beta 3 .

\section{Author contributions}

Conception and design: SSS, DH, RS, LN

Development of methodology: SSS, JS, LN

Acquisition of data: SSS, JS, HL, CW, LN

Analysis and interpretation of data: SSS, JS, HL, CW, LN, XL

Writing, review, and/or edit of the manuscript: SSS, LN, RS, SA, DH

Study supervision: SSS 


\section{ACKNOWLEDGMENTS}

This work was supported in part by the Department of Defense grant (W81XWH-16-1-0641). Funding from the Beckman Research Institute of the City of Hope is also acknowledged. We acknowledge and thank Prof. Yate-Ching Yuan, PhD, Director of Bioinformatics Core for the technical advice and strategic support provided during the conduct of these studies. We thank Shireen Chikara, PhD for RT-qPCR validation of RNA seq data. We also thank Jinhui Wang, PhD, Assistant Research Professor and Prof. Xiwei Wu, PhD, Research Professor and Director of Functional Genomics Core at City of Hope for streamlining the process of RNA sequencing and analyses. We acknowledge technical support from Pathology Core at City of Hope. We sincerely thank Ravi Salgia, MD, PhD, Professor and Chair, Department of Medical Oncology at City of Hope for providing research space and support.

\section{CONFLICTS OF INTEREST}

The authors declare that they have no conflicts of interest with the contents of this article.

\section{REFERENCES}

1. Howlader N, Noone AM, Krapcho M, Miller D, Bishop K, Kosary CL, Yu M, Ruhl J, Tatalovich Z, Mariotto A, Lewis DR, Chen HS, Feuer EJ, Cronin KA, Editors. SEER Cancer Statistics Review, 1975-2016, National Cancer Institute. Bethesda, MD, https://seer.cancer.gov/csr/1975_2016/, based on November 2016 SEER data submission, posted to the SEER web site, April 2017.

2. Brenton JD, Carey LA, Ahmed AA, Caldas C. Molecular classification and molecular forecasting of breast cancer: Ready for clinical application? J Clin Oncol. 2005; 23: 7350-7360.

3. Dawson SJ, Provenzano E, Caldas C. Triple negative breast cancers: Clinical and prognostic implications. Eur J Cancer. 2009; 45: 27-40.

4. Slamon DJ, Clark GM, Wong SG, Levin WJ, Ullrich A, McGuire WL. Human breast cancer: Correlation of relapse and survival with amplifcation of the HER-2/neu oncogene. Science. 1987; 235: 177-182.

5. Alary J, Bravais F, Cravedi JP, Debrauwer L, Rao D, Bories G. Mercapturic acid conjugates as urinary end metabolites of the lipid peroxidation product 4-hydroxy-2-nonenal in the rat. Chem Res Toxicol. 1995; 8: 34-39.

6. Awasthi S, Cheng J, Singhal SS, Saini MK, Pandya U, Pikula S, Bandorowicz-Pikula J, Singh SV, Zimniak P, Awasthi YC. Novel function of human RLIP76: ATPdependent transport of glutathione conjugates and doxorubicin. Biochemistry. 2000; 39: 9327-9334.
7. Singhal SS, Wickramarachchi D, Yadav S, Singhal J, Leake K, Vatsyayan R, Chaudhary P, Lelsani P, Suzuki S, Yang S, Awasthi YC, Awasthi S. Glutathione-conjugate transport by RLIP76 is required for clathrin-dependent endocytosis and chemical carcinogenesis. Mol Cancer Ther. 2011; 10: 16-28.

8. Singhal SS, Awasthi YC, Awasthi S. Regression of melanoma in a murine model by RLIP76 depletion. Cancer Res. 2006; 66: 2354-2360.

9. Singhal SS, Singhal J, Yadav S, Dwivedi S, Boor PJ, Awasthi YC, Awasthi S. Regression of lung and colon cancer xenografts by depleting or inhibiting RLIP76 (ralbinding protein 1). Cancer Res. 2007; 67: 4382-4389.

10. Awasthi S, Singhal SS, Awasthi YC, Martin B, Woo JH, Cunningham CC, Frankel AE. RLIP76 and Cancer. Clin Cancer Res. 2008; 14: 4372-4377.

11. Wang CZ, Yuan P, Xu B, Yuan L, Yang HZ, Liu X. RLIP76 expression as a prognostic marker of breast cancer. Eur Rev Med Pharmacol Sci. 2015; 19: 2105-2111.

12. Guarneri V, Conte P. Metastatic breast cancer: therapeutic options according to molecular subtypes and prior adjuvant therapy. Oncologist. 2009; 14: 645-656.

13. Newman DJ, Cragg GM. Natural products as sources of new drugs over the 30 years from 1981 to 2010. J Nat Prod. 2012; 75: 311-335.

14. Guthrie N, Carroll KK. Inhibition of mammary cancer by citrus flavonoids. Adv. Exp. Med. Biol. 1998; 439: 227-236.

15. Singhal J, Nagaprashantha L, Chikara S, Awasthi S, Horne D, Singhal SS. 2'-Hydroxyflavanone: a novel strategy for targeting breast cancer. Oncotarget. 2017; 8: 75025-75037. https://doi.org/10.18632/oncotarget.20499.

16. Lipinski CA, Lombardo F, Dominy BW, Feeney PJ. Experimental and computational approaches to estimate solubility and permeability in drug discovery and development settings. Adv Drug Deliv Rev. 2001; 46: 3-26.

17. Veber DF, Johnson SR, Cheng HY, Smith BR, Ward KW, Kopple KD. Molecular properties that influence the oral bioavailability of drug candidates. J Med Chem. 2002; 45: 2615-2623.

18. Singhal SS, Singhal J, Sharma R, Singh SV, Zimniak P, Awasthi YC, Awasthi S. Role of RLIP76 in lung cancer doxorubicin resistance: the ATPase activity of RLIP76 correlates with doxorubicin and 4-hydroxynonenal resistance in lung cancer cells. Int J Oncol. 2003; 22: 365-375.

19. Awasthi S, Singhal SS, Pikula S, Piper JT, Srivastava SK, Torman RT, Bandorowicz-Pikula J, Lin JT, Singh SV, Zimniak P, Awasthi YC. ATP-dependent human erythrocyte glutathione-conjugate transporter. functional reconstitution of transport activity. Biochemistry. 1998; 37: 5239-5248.

20. Friesner RA, Murphy RB, Repasky MP, Frye LL, Greenwood JR, Halgren TA, Sanschagrin PC, Mainz DT. Extra precision glide: Docking and scoring incorporating a model of hydrophobic enclosure for protein-ligand complexes. J Med Chem. 2006; 49: 6177-6196. 
21. Yu DD, Andrali SS, Li H, Lin M, Huang W, Forman BM. Novel FXR (farnesoid X receptor) modulators: Potential therapies for cholesterol gallstone disease. Bioorg Med Chem. 2016; 24: 3986-3993.

22. Shiozaki A, Shen-Tu G, Bai X, Iitaka D, De Falco V, Santoro M, Keshavjee S, Liu M. XB130 mediates cancer cell proliferation and survival through multiple signaling events downstream of akt. PLoS One. 2012; 7: e43646.

23. Span PN, Bussink J, Manders P, Beex LV, Sweep CG. Carbonic anhydrase-9 expression levels and prognosis in human breast cancer: Association with treatment outcome. Br J Cancer. 2003; 89: 271-276.

24. Hernandez-Fernaud JR, Ruengeler E, Casazza A, Neilson LJ, Pulleine E, Santi A, Ismail S, Lilla S, Dhayade S, MacPherson IR, McNeish I, Ennis D, Ali H, et al. Secreted CLIC3 drives cancer progression through its glutathionedependent oxidoreductase activity. Nat Commun. 2017; 8: 14206.

25. Macpherson IR, Rainero E, Mitchell LE, van den Berghe PV, Speirs C, Dozynkiewicz MA, Chaudhary S, Kalna G, Edwards J, Timpson P, Norman JC. CLIC3 controls recycling of late endosomal MT1-MMP and dictates invasion and metastasis in breast cancer. J Cell Sci. 2014; 127: 3893-3901.

26. Boyer-Guittaut M, Poillet L, Liang Q, Bole-Richard E, Ouyang X, Benavides GA, Chakrama FZ, Fraichard A, Darley-Usmar VM, Despouy G, Jouvenot M, DelageMourroux R, Zhang J, et al. The role of GABARAPL1/ GEC1 in autophagic flux and mitochondrial quality control in MDA-MB-436 breast cancer cells. Autophagy. 2014; 10: 986-1003.

27. Liu D, Xia H, Wang F, Chen C, Long J. MicroRNA-210 interacts with $\mathrm{FBXO} 31$ to regulate cancer proliferation cell cycle and migration in human breast cancer. Onco Targets Ther. 2016; 9: 5245-5255.

28. Shikama N, Lee CW, France S, Delavaine L, Lyon J, KrsticDemonacos M, La Thangue NB. A novel cofactor for p300 that regulates the p53 response. Mol Cell. 1999; 4: 365-376.

29. Pandey DP, Picard D. miR-22 inhibits estrogen signaling by directly targeting the estrogen receptor alpha mRNA. Mol Cell Biol. 2009; 29: 3783-3790.

30. Moore KM, Thomas GJ, Duffy SW, Warwick J, Gabe R, Chou P, Ellis IO, Green AR, Haider S, Brouilette K, Saha A, Vallath S, Chelala $\mathrm{C}$, et al. Therapeutic targeting of integrin alphavbeta6 in breast cancer. J Natl Cancer Inst. 2014; 106: 10.1093/jnci/dju169. Print 2014 Aug.

31. Trimarchi JM, Fairchild B, Wen J, Lees JA. The E2F6 transcription factor is a component of the mammalian Bmil-containing polycomb complex. Proc Natl Acad Sci U S A. 2001; 98: 1519-1524.

32. Broude EV, Demidenko ZN, Vivo C, Swift ME, Davis $\mathrm{BM}$, Blagosklonny MV, Roninson IB. p21 (CDKN1A) is a negative regulator of p53 stability. Cell Cycle. 2007; 6: 1468-1471.
33. Zhang JL, Liu Y, Yang H, Zhang HQ, Tian XX, Fang WG. ATP-P2Y2-beta-catenin axis promotes cell invasion in breast cancer cells. Cancer Sci. 2017; 108:1318-1327.

34. Spiegel S, Milstien S. Sphingosine-1-phosphate: An enigmatic signalling lipid. Nat Rev Mol Cell Biol. 2003; 4: 397-407.

35. David CJ, Huang YH, Chen M, Su J, Zou Y, Bardeesy $\mathrm{N}$, Iacobuzio-Donahue CA, Massagué J. TGF- $\beta$ Tumor Suppression through a Lethal EMT. Cell. 2016; 164: 1015-1030.

36. Pishvaian MJ, Feltes CM, Thompson P, Bussemakers MJ, Schalken JA, Byers SW. Cadherin-11 is expressed in invasive breast cancer cell lines. Cancer Res. 1999; 59: 947-952.

37. Patani N, Douglas-Jones A, Mansel R, Jiang W, Mokbel $\mathrm{K}$. Tumour suppressor function of MDA-7/IL-24 in human breast cancer. Cancer Cell Int. 2010; 10: 29.

38. Yoshida S, Pacitto R, Yao Y, Inoki K, Swanson JA. Growth factor signaling to $\mathrm{mTORC} 1$ by amino acid-laden macropinosomes. J Cell Biol. 2015; 211: 159-172.

39. Pohl SG, Brook N, Agostino M, Arfuso F, Kumar AP, Dharmarajan A. Wnt signaling in triple-negative breast cancer. Oncogenesis. 2017; 6: e310.

40. Sun B, Zhang S, Zhang D, Li Y, Zhao X, Luo Y, Guo Y. Identification of metastasis-related proteins and their clinical relevance to triple-negative human breast cancer. Clin Cancer Res. 2008; 14: 7050-7059.

41. Davison Z, de Blacquiere GE, Westley BR, May FE. Insulin-like growth factor-dependent proliferation and survival of triple-negative breast cancer cells: Implications for therapy. Neoplasia 2011; 13: 504-515.

42. Sunkel CE, Glover DM. Polo, a mitotic mutant of drosophila displaying abnormal spindle poles. J Cell Sci. 1988; 89: 25-38.

43. Zhang Y, Jiang C, Li H, Lv F, Li X, Qian X, Fu L, Xu B, Guo X. Elevated aurora B expression contributes to chemoresistance and poor prognosis in breast cancer. Int $\mathrm{J}$ Clin Exp Pathol. 2015; 8: 751-757.

44. Chen C, Zhao KN, Masci PP, Lakhani SR, Antonsson A, Simpson PT, Vitetta L. TGFbeta isoforms and receptors mRNA expression in breast tumours: Prognostic value and clinical implications. BMC Cancer. 2015; 15: 1010.

45. Jovanovic B, Beeler JS, Pickup MW, Chytil A, Gorska AE, Ashby WJ, Lehmann BD, Zijlstra A, Pietenpol JA, Moses HL. Transforming growth factor beta receptor type III is a tumor promoter in mesenchymal-stem like triple negative breast cancer. Breast Cancer Res. 2014; 16: R69.

46. Tian S, Roepman P, Van't Veer LJ, Bernards R, de Snoo F, Glas AM. Biological functions of the genes in the mammaprint breast cancer profile reflect the hallmarks of cancer. Biomark Insights. 2010; 5: 129-138.

47. Singhal J, Nagaprashantha L, Vatsyayan R, Awasthi S, Singhal SS. RLIP76, a glutathione-conjugate transporter, 
plays a major role in the pathogenesis of metabolic syndrome. PLoS One. 2011; 6: e24688.

48. Singhal SS, Figarola J, Singhal J, Reddy MA, Liu X, Berz D, Natarajan R, Awasthi S. RLIP76 protein knockdown attenuates obesity due to a high-fat diet. J Biol Chem. 2013; 288: 23394-23406.

49. Fenwick RB, Campbell LJ, Rajasekar K, Prasannan S, Nietlispach D, Camonis J, Owen D, Mott HR. The RalBRLIP76 complex reveals a novel mode of ral-effector interaction. Structure. 2010; 18: 985-995.

50. Wurtzel JG, Lee S, Singhal SS, Awasthi S, Ginsberg MH, Goldfinger LE. RLIP76 regulates Arf6-dependent cell spreading and migration by linking ARNO with activated R-ras at recycling endosomes. Biochem Biophys Res Commun. 2015; 467: 785-791.

51. Wu Z, Owens C, Chandra N, Popovic K, Conaway M, Theodorescu D. RalBP1 is necessary for metastasis of human cancer cell lines. Neoplasia. 2010; 12: 1003-1012.

52. Minicozzi P, Berrino F, Sebastiani F, Falcini F, Vattiato R, Cioccoloni F, Calagreti G, Fusco M, Vitale MF, Tumino R, Sigona A, Budroni M, Cesaraccio R, et al. High fasting blood glucose and obesity significantly and independently increase risk of breast cancer death in hormone receptorpositive disease. Eur J Cancer. 2013; 49: 3881-3888. 